\title{
Central Bank Independence and Inflation: The Matters of Financial Development and Institutional Quality
}

\author{
Agung Kunaedi ${ }^{1}$, Darwanto ${ }^{2 *}$ \\ ${ }^{*}$ Corresponding author
}

\begin{abstract}
The inverse relationship between the independence of the central bank (CBI) and inflation became a consensus that trusted throughout the world. However, there is no conclusive explanation of why and how central bank independence has succeeded in suppressing inflation. The purpose of this study is to examine the influence of financial development and institutional quality on the relationship between central bank independence and inflation. Using 20 Countries of Asia with institutional diversity, this study analyzed through a dynamic panel approach (GMM-Arellano and Bond Estimator). The result indicates that the inverse relationship between central bank independence and inflation depends on the development of the financial sector and also the institutional quality of each country. In other words, to make the central bank's independence work effectively in order to solve bias inflation, the improvement of the financial sector and also the institutional quality is needed.
\end{abstract}

Keywords: central bank independence, inflation, institutional quality

\begin{abstract}
Abstrak
Hubungan negatif antara independensi bank sentral (CBI) dan inflasi menjadi konsensus yang dipercaya di seluruh dunia, namun belum ada penjelasan konklusif tentang mengapa dan bagaimana independensi bank sentral telah berhasil menekan inflasi. Tujuan dari penelitian ini adalah untuk menguji, pengaruh kualitas kelembagaan pada hubungan independensi bank sentral dan inflasi. Menggunakan 20 Negara Asia dengan keragaman institusional, studi ini dianalisis melalui pendekatan panel dinamis (GMM-Arellano dan Bond Estimator). Hasilnya menunjukkan bahwa hubungan negatif antara independensi bank sentral dan inflasi tergantung pada pengembangan sektor keuangan dan kualitas kelembagaan masing-masing negara. Studi ini menyarankan agar independensi bank sentral efektif dalam rangka mengatasi masalah bias inflasi, pengembangan pada sektor keuangan dan kualitas kebutuhan menjadi hal kunci.
\end{abstract}

Kata Kunci: independensi bank sentral, inflasi, kualitas kelembagaan

JEL Classification : E580, E310, E020

\section{How to Cite:}

Kunaedi, A., \& Darwanto. (2020). Central Bank Independence and Inflation: The Matters of Financial Development and Institutional Quality. Signifikan: Jurnal IImu Ekonomi, Vol. 9(1), 1-14. doi: http://dx.doi. org/10.15408/sjie.v9i1.12899. 


\section{Introduction}

Central bank independence is not a new topic in the literature, and even David Ricardo (1824) has discussed this topic (Issing, 2018). The emergence of a discussion on the independence of the central bank is motivated by the experience of the central bank when under the control of the government that encourages the central bank to conduct accommodative monetary policy to accommodate the interests of the government, so the monetary policy will lose its ability to control the inflation rate (Warjiyo \& Juhro, 2017). The independence of the central bank has again become a massive topic discussed since the 1970 crisis. The question of why the central bank is unwilling or able to keep inflation under control is a trigger for discussion of central bank independence following the theoretical findings of Kydland \& Prescott (1977) about time inconsistencies in monetary policy. Then, Barro \& Gordon (1983), in their theoretical model, discussed the credibility of monetary policy and continued by Rogoff (1985) who stated the importance of delegation of authority to agents who are independent and conservative towards inflation to overcome time inconsistencies and enhance the credibility of monetary policy. Rogoff became the theoretical founder of central bank independence, which then linked to the central bank's goal of maintaining price stability (low and stable inflation) (Rochon \& Olawoye, 2013).

Rogoff (1985) states that an independent and conservative central bank in controlling inflation (inflation-averse) will tend to reduce the average inflation rate, but increase output volatility. In other words, a conservative central bank can reduce inflation bias due to the time inconsistency of monetary policy, but on the other hand, it has less role in maintaining the stability of output (Warjiyo \& Juhro, 2017). Time inconsistency itself is a problem that arises when policy authorities face a dilemma in determining policy preferences between times. It happens when policy authorities implement specific policies to achieve a low and stable level of inflation. However, after economic actors respond by setting nominal wage levels based on low inflation expectations, the policy authority is tempted to tolerate an inflation rate higher than the inflation rate that has set in order to encourage output and a higher level of employment. This condition can cause economic actors, in the next period, to not trust the policy that will be taken by the policy authority, or in other words, the credibility of the policy authority will be lost.

Cukierman et al. (1992) prove the existence of an inverse relationship between central bank independence, especially legal independence and inflation rates in developed countries. This empirical finding then led to a broad consensus that the optimal law for the central bank must base on the principle of independence and a clear mandate for price stability or low inflation. Since then, there has been a strong consensus (theoretically supported empirically) that the independence of the central bank is the solution to curbing inflation. Further empirical research also continues to confirm this. Alesina \& Summers (1993), for example, even stated in their writing that the independence of the central bank was a free lunch because there was nothing to sacrifice to achieve growth. As a result, the independence index of the central bank (legal independence) rose in all countries in the world. The central bank's independence index then peaked before the 2008 financial crisis (Masciandaro and Romelli, 2015). One thing that seems forgotten is that the consensus of 
the negative relationship between central bank independence and inflation is only found in developed countries, not in developing countries. As if forgetting the characteristics of developed and developing countries those are indeed different.

Central bank independence continues to rise in various countries, even after the crisis in 2008 (Bodea \& Hicks, 2014). In developing countries, several empirical studies (Cukierman et al., 1992; Hielscher \& Markwardt, 2012; Klomp \& de Haan, 2010) did not find a negative relationship between central bank independence and inflation rates. Other research shows that there is a negative relationship between central bank independence and inflation in certain conditions, for example, improvement in institutional quality (Agoba et al., 2017; Bouoiyour \& Selmi, 2013; Hove et al., 2017; Salahodjaev \& Chepel, 2014). Other studies have found a negative relationship between the independence of central banks in developing countries (Andriani \& Gai, 2013; Garriga \& Rodriguez, 2019; Nagac \& Rizvanoghlu, 2018). The diversity of the results of these studies, indicating the answer to the relationship between central bank independence and inflation is still a topic that continues to be discussed, and there is a research gap that has to be answered.

Cukierman et al. (1992) state that the reason why there is no negative relationship between central bank independence and inflation in developing countries due to differences between de facto and de jure. In other words, there is a disregard for laws in developing countries where even though the central bank has been given independence, political authorities do not comply with these regulations. So, the independence of the central bank is useless because good institutions do not support it. Posen (1995) corroborates the statement by stating that low inflation as a result of central bank independence. It is not only because of high independence but also reflects the existence of a strong financial sector and jointly supported by the strength of political constituencies that oppose inflation. Acemoglu et al. (2008), also states that distortions that produce higher inflation before the independence of the central bank can appear in other ways under the independence of the central bank. So central bank independence is not enough; it needed support, and institutional quality is one that widely discussed in the literature as determining the relationship between central bank independence and inflation.

There are at least two channels in which the development of the financial sector influences achievement of the inflation target: (i) the role of the financial sector in reducing government dependence on seigniorage (Neyapti, 2003); and (ii) the mechanism of credit channel transmission (Bernanke \& Blinder, 1988; Bernanke \& Gertler, 1995). When the financial sector is underdeveloped, fiscal dominance will flourish because the government depends on the central bank to finance its budget deficit. However, when financial markets are more developed, it is easier for the government to finance its budget deficit from the money market without relying on seigniorage. As for the credit channel mechanism of monetary policy, a developing financial sector is needed. Transmission of interest rate movements to influence output, prices, and ultimately inflation depends on the structure of the financial system. A developing financial system can send monetary impulses faster than a shallow financial system.

How about institutional quality? Why it matters? Institutional quality notably related to the level of political stability, the rule of law, and respect for civil rights is a reflection of 
the will of the government and the ability to respect the legal provisions made (Hielscher \& Markwardt, 2012). In relation to the central bank, the institutional element mentioned above is to ensure that the central bank remains independent of government interference in maintaining low inflation (Aisen \& Veiga, 2008). Institutional quality measurement is a potential instrument for legal independence (Crowe \& Meade, 2008) Supporting this statement, (Garriga \& Rodriguez, 2019) also found that the independence of the central bank would be more effective in suppressing inflation in countries with high levels of democracy. In addition, empirical research shows that politically unstable countries have higher inflation rates (Salahodjaev \& Chepel, 2014; Khan \& Hanif, 2018).

This research is intended to answer the question whether the independence of central banks in Asian countries can reduce the inflation rate and whether the institutional quality which is widely regarded as a support system for central bank independence in previous research has an effect on the relationship of central bank independence on inflation? The literature regarding the relationship between the independence of central banks and inflation rates in developing countries, especially in Asia, still limited, and conclusive answers have not yet been found. There are certain conditions needed for central bank independence in suppressing the inflation rate. So this study contributed to the literature. Using 20 countries in Asia, with a post-crisis observation period of 2008 (2008-2017), this study examines this empirically through a dynamic panel approach (GMM-Arellano and Bond Estimator) as an analysis tool.

\section{Methods}

This study has the core variables of the inflation rate and the independence of the central bank with the control variables in the form of (1) previous period inflation rate; (2) primary balance; (3) exchange rate regime (4) money growth and economic growth difference; (5) financial sector development; and (6) institutional quality. Besides, in the model two empirical, namely the interaction term model, to see the relationship between the independence of the central bank and inflation with moderating variables of institutional quality (for details shows in Table 1).

This study uses 2008-2017 panel data of 20 Asian countries, including: Bangladesh, China, Indonesia, India, Iran, Iraq, Israel, Jordan, Japan, Kazakhstan, Korea, Malaysia, Oman, Pakistan, Qatar, Singapore, Thailand, Turkey, Russia, and Srilanka.

The analytical method used in this study is the dynamic panel method. Panel data analysis can be used on dynamic models because panel data is suitable for the dynamic of adjustment analysis. In line with the existence of a cross-section or time series model, dynamic relationships are characterized by panel data by including lags of variables or dependent variables as regressors in regression. As a result, endogeneity problems arise, so if the model is estimated with a fixedeffect or random-effect approach, it will produce biased and inconsistent predictors.

For this reason, the GMM (Generalized Method of Moments) approach emerged. As an illustration, it can be seen with the dynamic panel data model that has been proposed by Baltagi (2005) as follows: 


$$
y_{i t}=\delta y_{i, t-1}+X_{i t}^{T} \beta+u_{i t \ldots \ldots \ldots \ldots \ldots \ldots \ldots \ldots \ldots \ldots \ldots \ldots \ldots \ldots \ldots \ldots \ldots \ldots \ldots \ldots \ldots \ldots \ldots \ldots \ldots \ldots \ldots \ldots \ldots}
$$

where $\delta$ expresses the scalar sale, $\mathrm{x}_{\mathrm{it}}$ expresses $1 \mathrm{x} k$ sized matrix; and $\beta$ is $k \mathrm{x} 1$ sized matrix. In this case, $\varepsilon_{\mathrm{it}}$ is assumed to follow one way error component model as follows:

$$
u_{i t}=\omega_{i t}+\pi_{i t}
$$

where $\omega_{i} \sim \operatorname{IID}\left(0, \sigma_{\dot{\omega}}^{2}\right)$ expresses individual influence; and $\pi_{i} \sim \operatorname{IID}\left(0, \sigma_{\pi}^{2}\right)$ expresses eror that is

\begin{tabular}{|c|c|c|c|}
\hline Variables & Operational Descriptions & Unit & Source \\
\hline Inflation rate & GDP Deflator Rate, modified & $\%$ & Worldbank \\
\hline $\begin{array}{l}\text { Central Bank } \\
\text { Independence }\end{array}$ & Central bank Independence index & Index & Garriga (2016) \\
\hline Primary Balance & Primary Balance & $\%$ of GDP & Fiscal Monitor, IMF \\
\hline $\begin{array}{l}\text { Exchange Rate } \\
\text { Regime }\end{array}$ & $\begin{array}{l}\text { Dummy Variable; } 1 \text { Fixed exchange } \\
\text { rate regime; } 0 \text { free floating }\end{array}$ & 0 or 1 & $\begin{array}{l}\text { Ilzetzki, Reinhart } \\
\text { and Rogoff (2017) }\end{array}$ \\
\hline Monetary Base & $\begin{array}{l}\text { Difference of M2 growth and } \\
\text { Economic growth }\end{array}$ & $\%$ & World Bank, diolah \\
\hline $\begin{array}{l}\text { Financial } \\
\text { Development }\end{array}$ & $\begin{array}{l}\text { Ratio of domestic private sector } \\
\text { credit to GDP }\end{array}$ & $\%$ of GDP & World Bank \\
\hline Institutional Quality & Political Right Score, modified & Scale (0-6) & FreedomHouse \\
\hline Trade Openness & $\begin{array}{c}\text { Ratio of total exports and imports } \\
\text { to GDP }\end{array}$ & $\%$ of GDP & World Bank \\
\hline
\end{tabular}
free krom each other.

Table 1. Operational Variable

Sources: author processed from various sources

A simple way to detect the presence of weak instrument variables is to test the instrument's validity using the Sargan Specification Test. If the instrument variable used is weak, then the parameters generated by GMM-diff will still experience downward bias. The null hypothesis $(\mathrm{H} 0)$ in the Sargan test is that overidentifying restrictions are valid. Post estimation in the dynamic panel is a partial and simultaneous test.

The use of the dynamic panel model, GMM-Arellano and Bond Estimator, is based on special treatment of the endogeneity of inflation. This study explains inflation persistence by incorporating inflation lag into the model. The general specifications of the model used are as follows:

$$
\pi_{i, t}=\alpha_{0}+\delta \pi_{i, t-1}+\alpha_{1} C B I_{i, t}+\gamma Z_{i, t}+u_{i, t}
$$

The interaction model is used to analyze the impact of institutional quality and financial development on central bank independence inflation with the following specifications:

$$
\pi_{i, t}=\alpha_{0}+\delta \pi_{i, t-1}+\alpha_{1} C B I_{i, t}+\beta\left(C B I_{i, t} * C V_{i, t}\right)+\gamma Z_{i, t}+u_{i t}
$$

Where CV is a conditional variable, in this study is financial development and institutional quality. The conditional variable then becomes a slope in the relationship between the central bank independence variable and inflation. 


$$
\pi_{i, t}=\alpha_{0}+\delta \pi_{i, t-1}+\left(\alpha_{1}+(\beta * C V)\right) C B I_{i, t}+\gamma Z_{i, t}+u_{i, t}
$$

Where $=\left(\alpha_{1}+\left(\beta * C V_{i, t}\right)\right)=\Pi$, so:

$$
\pi_{i, t}=\alpha_{0}+\delta \pi_{i, t-1}+\Pi C B I_{i, t}+\gamma Z_{i, t}+u_{i, t}
$$

The above equation indicates, when $\Pi=0$, then the conditional variable does not affect the relationship between the central bank independence (CBI) and inflation, $\Pi=0$ is obtained from:

$$
\begin{aligned}
& 0=\Pi=\alpha_{1}+\left(\beta * C V_{i, t}\right) \\
& 0=\alpha_{1}+\left(\beta * C V_{i, t}\right) \\
& C V_{i, t}=-\frac{\alpha_{1}}{\beta} \text {. }
\end{aligned}
$$

The description of variables and parameters in the empirical model ( 3 and 3 ') is explained in Table 2 as follows:

Table 2. Description Model

\begin{tabular}{cc}
\hline Variables/Parameters & Description \\
\hline$\alpha_{1}$ & Parameter of FCB influence on inflation \\
$\delta$ & Parameter of lagged dependent variables (LDV) \\
$\gamma \mathrm{Z}_{\mathrm{i}, \mathrm{t}}$ & Group of parameters and control variables \\
$\mathrm{CBI}_{\mathrm{i}, \mathrm{t}}$ & Central Bank Independence \\
$\Pi_{(\mathrm{i}, \mathrm{t})}$ & Interaction Variabel parameters \\
FinDev & Financial sector development \\
InstQual & Institutional quality \\
\hline
\end{tabular}

Source: Compiled by the author

\section{Results and Discussion}

In this study, the measurement of inflation is based on the GDP Deflator growth value approach obtained from Worldbank. Specifically, the measurement of inflation will use the transformation method following Agoba et al. (2017). The inflation variable was modified to avoid outliers and heteroscedasticity problems. This research uses the GDP deflator compared to the average consumer price index because the GDP deflator is more able to cover many aspects compared to the consumer price index.

Meanwhile, the central bank independence index used in this study is the legal independence index obtained from Garriga (2016). The central bank legal independence index is based on a weighted aggregation of 16 indicators in four categories. The four categories are the term of office of the bank governor, the formation of policies, objectives, and restrictions on loans to the government where the score calculation uses criteria and weights built by Cukierman et al. (1992). Indices vary between 0 and 1 with a greater value indicating greater independence.

Financial development indicators are measured by the ratio of domestic private credit to GDP. The financial sector development variable reflects domestic credit to the private sector, referring to financial resources provided to the private sector by financial companies, such as 
through loans, securities purchases, trade credit, and others. Financial corporations include banks and other financial corporations such as finance and leasing companies, moneylenders, insurance companies, pension funds, and foreign exchange companies. The higher the ratio of private domestic credit means, the better the intermediary role of the financial system that means the development of the financial sector. The banking sector chooses because the financial sector in Asia still dominates by the banking sector (Eichengreen, 2015).

The political right score of freedom house used in this study is a proxy of institutional quality. Political right scores contain information that can represent political dynamics in the countries observed in this study. The variable political rights (PR) captures the extent to which the electoral process is free and fair, the state of pluralism in a country, political participation, political turmoil, and the sustainability of government functions, including contract enforcement or the rule of law. Scores for variables range from 7 to 1, with 7 representing the lowest ranking and one highest. Following Bodea and Higashijima (2017), the score for institutional quality can transform into $0-6$, so the lower score corresponds to a lower ranking of political rights, and a higher score corresponds to a ranking of higher political rights. The formula does the transformation:

$$
-1 *(\text { PRS }-7)
$$

Where PRS is the score of political rights granted by Freedom House. The higher the political right score, the country is judged by freedom house, the more stable its politics. The more stable the political conditions, the more effective the independence of the central bank.

Table 3.Descriptive statistics

\begin{tabular}{crrrrr}
\hline Variables & Obs & Mean & Std. Dev. & Min & Max \\
\hline Inflation & 200 & 0.020967 & 0.0369561 & -0.1313556 & 0.1321554 \\
Central Bank Independence & 200 & 0.5314116 & 0.1679357 & 0.1345 & 0.904 \\
Financial Development & 200 & 71.0481 & 45.26753 & 2.68222 & 169.0694 \\
Primary Balance & 200 & -0.2244027 & 4.797718 & -21.6435 & 24.00892 \\
Monetary Base & 200 & 7.984984 & 8.618775 & -11.59959 & 44.68322 \\
Exchange Rate Regime & 200 & 0.915 & 0.2795815 & 0 & 1 \\
Institutional Quality & 200 & 2.775 & 1.903283 & 0 & 6 \\
Trade & 200 & 84.97491 & 72.3072 & 24.4909 & 441.6038 \\
\hline
\end{tabular}

Source: processed by author using STATA 14

Note: (i) observation of time covers the years 2003-2017, annual; (ii) the value of the central bank independence index variable is assumed to be constant from 2012 to 2017, due to the limited availability of data and the character of the index value that tends to be constant between times;

Descriptive statistics in Table 3 show that the average independence of the central bank in the country observed is 0.53 . This data means de facto, the central banks of the countries observed in general, have relatively high independence. Then the question arises with the level of independence that own can be a deterrent to monetary policy distortion from politicians who are then able to eliminate the inflation bias so that inflation becomes lower than before. 
Table 4. Output Analysis

\begin{tabular}{|c|c|c|c|}
\hline \multicolumn{4}{|c|}{ Dependent Variable: Inflation Rate } \\
\hline \multirow{2}{*}{ Inflation (t-1) } & $0.3119239^{* * *}$ & $0.3065506^{* * *}$ & $0.3246711^{* * *}$ \\
\hline & {$[0.0143719]$} & {$[0.0139628]$} & [0.0227239] \\
\hline \multirow{2}{*}{ Central Bank Independence } & $0.1829701^{* * *}$ & $0.451729^{* * *}$ & $0.2800373^{* * *}$ \\
\hline & {$[0.0444573]$} & {$[0.0422156]$} & {$[0.0660303]$} \\
\hline \multirow{2}{*}{ Primary Balance } & $-0.0027335^{* * *}$ & $-0.0023996^{* * *}$ & $-0.0023147^{* * *}$ \\
\hline & {$[0.0003641]$} & {$[0.0003656]$} & {$[0.000261]$} \\
\hline \multirow{2}{*}{ Exchange Rate Regime } & $-0.0236414^{* * *}$ & $-0.0258264^{* * *}$ & $-0.0233002^{* * *}$ \\
\hline & {$[0.0033339]$} & {$[0.0029617]$} & {$[0.0030126]$} \\
\hline \multirow{2}{*}{ Monetary Base } & $0.0003099^{* *}$ & $0.0003693^{* * *}$ & $0.0002598^{*}$ \\
\hline & {$[0.0001584]$} & {$[0.0001134]$} & {$[0.0001454]$} \\
\hline \multirow{2}{*}{ Trade Openness } & $0.0004385^{*}$ & 0.0002627 & 0.0003876 \\
\hline & {$[0.0002392]$} & {$[0.0002105]$} & {$[0.0002539]$} \\
\hline \multirow{2}{*}{ Financial Development } & $-0.0016664^{* * *}$ & & $-0.0018334^{* * *}$ \\
\hline & {$[0.000201]$} & & {$[0.0001839]$} \\
\hline \multirow{2}{*}{ Institutional Quality } & $-0.015135^{* * *}$ & $-0.0135954^{* * *}$ & \\
\hline & {$[0.0033498]$} & {$[0.0032221]$} & \\
\hline \multirow{2}{*}{ Findev*CBI } & & $-0.0032566^{* * *}$ & \\
\hline & & {$[0.0003679]$} & \\
\hline \multirow[t]{2}{*}{ Institutional Quality*CBI } & & & $-0.0237079^{* * *}$ \\
\hline & & & {$[0.0043964]$} \\
\hline \multirow{2}{*}{ Constanta } & $0.1109075^{* * *}$ & & $0.0597101^{* *}$ \\
\hline & {$[0.0312591]$} & & {$[0.0254739]$} \\
\hline Wald-Stat (8) & $14808.38^{* * *}$ & 3223.03 & $23097.4^{* * *}$ \\
\hline Number of Instrument & 44 & 44 & 44 \\
\hline Number of Observation & 160 & 160 & 160 \\
\hline Number of Group (Countries) & 20 & 20 & 20 \\
\hline $\operatorname{AR}(1)$ & $-1.791^{*}$ & -2.0842 & $-2.2215^{* *}$ \\
\hline$A R(2)$ & 1.6396 & 1.6427 & -1.6427 \\
\hline Sargan Test (Chi-Squared ) ( $\chi 2)$ & 15.61641 & 14.6575 & 15.26768 \\
\hline
\end{tabular}

Source: processed by author using STATA 14

Note: (i) respectively, the signs ${ }^{*},{ }^{* *}$, and ${ }^{* * *}$ describe the significance level of 10 percent, 5 percent, and 1 percent; (ii) the number in parentheses, [], is the standard error value; and (iii) the Arellano GMM estimation model and Bond Estimator (two-step consistent estimator).

The results of the study in Table 4 shows that the independence of the central bank had a significant positive correlation to the level of inflation where when the central bank became more independent (marked by the central bank independence index de jure higher), then inflation would also be higher. The findings in this study are, of course, very contrary to theoretical constructs, as well as empirical research by Cukierman et al. (1992); Alesina \& Summers, (1993); Klomp \& de Haan (2010b); and Garriga \& Rodriguez (2019). But, this study consistent with previous research such as: Agoba et al. (2017), Farvaque (2002), Haan 
\& Eijffinger (2016), Hartwell (2019), Hielscher \& Markwardt (2012), Hove et al. (2017), Khan \& Hanif (2018), Posen (1995). The independence of the central bank alone is not enough, but it requires good institutional quality. So the independence of the central bank is able to run effectively in eliminating distortions of monetary policy and inflation bias.

The central bank cannot be completely free from political distortion, even though the central bank has legal independence. In particular, the central bank is part of a government that cannot be separated from political problems. Central banks, by definition, are monetary institutions that are embedded in a wider system of economic and political institutions, both domestically and internationally (Hartwell, 2019). The institutional perspective also sees that the central bank is an institution in an institutional system, the central bank is part of governance in a broad sense like the legislative, executive, and judicative (Oritani, 2010). As part of governance, the central bank interacts with other government agencies in a country's governance structure. So it is difficult for the central bank to gain full independence given the high central bank interdependence with other government agencies.

The interaction of the central bank with the government does not have a direct relationship with the government. This is due to the independence of the central bank. The central bank, however, has indirect contacts, which deal with responsive actions such as providing information to the government. Although the central bank and the government, do not have direct contact or direct interaction because the central bank has independence, it is not uncommon for the government which in fact is a politician with a limited term following the political cycle to put "pressure" on the central bank which is an institution with a term that does not follow political cycle. Moreover, if the central bank is not politically independent, then the central bank is not sovereign; the interactions that arise are direct contacts.

In the aftermath of the 2008 crisis as economic growth weakened and the populist wave grew, elected leaders tried to regain economic control - and put the central bank in a defensive position. The effect is greatest in developing countries in Asia, where the position of the central bank is often weaker than in developed countries. Especially in the countries observed, the independence of the central bank is increasingly being suppressed by political dynamics. For example, in India, central bank governor Urjit Patel suddenly resigned after a long debate with Prime Minister Narendra Modi. The government pressured the Reserve Bank of India to surrender more of its surplus to finance the budget deficit. The government also threatened to submit laws that were never used to provide more liquidity and ease lending rules in the midst of the banking crisis.

Even in developed countries like Korea, the first interest rate increase in 10 years has drawn criticism that the central bank is out of sync with the state of the economy in Korea. With the weakest labor market conditions in nine years, the Korean government continues to increase pressure on the central bank governor to relax his monetary policy. The Bank of Japan agreed to coordinate its policies with the government at the expense of its independence. The most phenomenal case with the highest degree of independence in this observation is Turkey. President Erdogan criticized Turkey's central bank for raising interest rates to reduce inflation and then claiming the power to be a determinant of bank interest rates. In addition, 
Endorgan also put his son-in-law in charge of economic policy. Similar pressures also occur in Pakistan and Russia

With these circumstances, it is natural, why in this study, the independence of the central bank has a positive effect on inflation. The independence of the central bank in the countries observed is only de jure independent, not so with the de facto. The inability to eliminate monetary policy distortions from politicians makes monetary policy accommodative to the interests of politicians, which in turn produces inflationary bias. Furthermore, countries in Asia are still dealing with democratic issues such as legislative development, corruption prevention, citizen participation in every policy, and constitutional and election reform (The National Democratic Institute, 2019). Then the political dynamics that occur will inevitably continue to influence and become a distortion in the policies taken by the central bank.

Market institutions, in this case, the financial sector, determine whether the policies pursued by the central bank can respond to the ultimate goal of the policy or not. Market institutions, in this case, the financial market, are mediators or intermediaries of policies from the central bank to the ultimate goal of the policy through monetary policy channels called monetary policy transmission. In particular, in the countries observed, financial market institutions have a heterogeneous nature.

Since the 1980s and especially since the 1990s, many developing countries in Asia have made significant efforts to liberalize and broaden the scope and depth of their financial sector, despite the substantial heterogeneity across countries regarding the time of reform (Didier \& Schmukler, 2014 ). This liberalization reached the Asian crisis of 1997-1998, which was mainly due to the failure of the region to build a deeper, more liquid, and more diverse financial system (Eichengreen, 2015).

Estimation results in this study indicate that the interaction variable between the independence of the central bank and the development of the financial sector has a negative and significant direction towards inflation. The independence of the central bank accompanied by increased development of the financial sector can reduce inflation

Institutional quality, which is represented by the political right score, is also a critical gap between de facto and de jure from the independence of the central bank. The worse the institutional quality represented by, the smaller the political right score of a country. The institutional quality that includes: the extent to which the election process is free and fair; the state of pluralism of a country; political participation; political turmoil; the sustainability of government functions including contract enforcement or the rule of law is getting worse so that it can become a distortion of monetary policy. This condition is evident from the interaction variables that negatively correlate to the inflation rate. In other words, the independence of the central bank accompanied by good institutional quality can be a barrier to the distortion of monetary policy so that monetary policy is not time-inconsistent, and inflation bias can be suppressed (Hielscher \& Markwardt, 2012; Rochon \& Olawoye, 2013). Warjiyo \& Juhro (2017) state for countries with low unemployment, preferences for high price stability, and stable political conditions, the possibility of inflation bias is minimal, even though the central bank is not independent, however. 
Institutional quality, such as the rule of law, is an essential benchmark in the measurement of public trust in the contract / applicable rules. The more respected the law/ rules/contracts, the more organized the behavior of individuals, which finally, every policy can be applied (Hayo \& Hefeker, 2001; Hayo \& Voigt, 2007). Besides, respect for contracts/ rules (the rule of law) as an indicator of trust in the legal system may also indirectly reflect the level of trust in government institutions, including the central bank, assuming the more an institution abiding by contracts/rules made, the more credible these institutions so that it has direct implications on low inflation expectations (Busse \& Hefeker, 2007).

Besides, this study also found that other control variables: monetary policy, exchange rate regime fiscal policy, and trade openness affect inflation rates. Exchange rate regimes find increasingly floating more inflationary. This condition is different from the conception of Agoba et al. (2017), who found that the fixed exchange rate increased inflation because the independence of the central bank was increasingly depressed by exchange rate volatility. However, the results of this study also support Bouoiyour and Selmi (2013), who found that the exchange rate remained counter to inflation. This result can explain, because inflation in Asian countries depends on world inflation rates so that exchange rate fluctuations can increase inflation, especially in Asia (International Monetary Fund, 2018).

The expansionary monetary policy will cause the higher the inflation rate. A negative primary balance has a positive effect on the inflation rate, meaning that expansionary policies will cause higher inflation. So that policy coordination is needed in achieving low and stable inflation. This finding reinforces the previous argument that the central bank is indeed part of an institutional system that has high interdependence with other institutions, both domestically and internationally. Stiglitz (1998) revealed that monetary policy is only one of the main determinants in the macroeconomic policy framework. Monetary policy is just one determinant of what is happening to society, and it needs support and coordination with other policies.

As for the trade openness variable, because most of the countries observed are developing countries, the results show that the higher the ratio of exports and imports to GDP, the possibility of exposure to external shocks and more significant global inflation. So in this study, the trade openness variable has a positive effect on inflation, although it is not significant.

\section{Conclusion}

When using a more appropriate estimator and model, taking into account the effects of lag inflation on the dependent variable, a direct negative relationship between the independence of the central bank and inflation, is not found in twenty countries in Asia, an interesting fact in this empirical study. Then the next question is, why? This study has found three things that cause the independence of the central bank have a positive effect on the level of inflation in this study are: First, distortion from politicians can still influence even though the central bank has independence. Second, central bank interdependence as part of an institutional system does not allow the central bank to be independent. Third, de jure independence is different from de facto independence. Thus, the independence of the central bank is not enough. Other elements are needed to participate and strengthen the 
independence of the central bank so that it is effective in suppressing the rate of inflation. The interaction variables show a negative relationship with the level of inflation.

This result implements the banking intermediary function that must be continuously improved, considering that the financial system in Asia still depends on the banking sector. With an excellent intermediary function, the effectiveness of the monetary policy transmission mechanism, primarily through the credit channel discussed in this study, is getting better. Whereas institutional quality ensures that central bank transactions with other institutions in the institutional system run well following existing contracts so that distortions from politicians can eliminate. So it is not to increase the independence of the central bank as a solution to policy distortion, but to develop a system of supporting the independence of the central bank is a solution. If the supporting system can develop central bank independence is not only de jure but also de facto.

\section{Acknowledgment}

We are thankfully to Bank Indonesia for facilitating financial assistance in this research.

\section{References}

Acemoglu, A., Johnson, S., Querubín, P., \& Robinson, J. A. (2008). When Does Policy Reform Work?: The Case of Central Bank Independence. Brookings Papers on Economic Activity, 2008, 351-418. https://doi.org/10.1353/eca.0.0002

Agoba, A. M., Abor, J., Osei, K. A., \& Sa-Aadu, J. (2017). Central Bank Independence and Inflation in Africa: The Role of Financial Systems and Institutional Quality. Central Bank Review, 17(4), 131-146. https://doi.org/10.1016/j.cbrev.2017.11.001

Aisen, A., \& Veiga, F. J. (2008). Political Instability and Inflation Volatility. Public Choice, 135(3), 207-223. https://doi.org/10.1007/s11127-007-9254-x

Alesina, A., \& Summers, L. H. (1993). Central Bank Independence and Macro Performance. Journal of Money, Credit and Banking, 25(2), 151-162. https://doi.org/ 10.2307/2077833.

Andriani, Y., \& Gai, P. (2013). The Effect of Central Bank Independence on Price Stability: the Case of Indonesia. Buletin Ekonomi Moneter Dan Perbankan, 15(4), 367-390. https://doi.org/10.21098/bemp.v15i4.72

Baltagi, B. H. (2005). Econometric Analysis of Panel Data (3rd Edition). England: John Wiley $\&$ Sons Ltd.

Barro, R. J., \& Gordon, D. B. (1983). Rules, Discretion and Reputation In a Model of Monetary Policy. NBER Working Paper Series, 1079, 364-388.

Bernanke, B. S., \& Blinder, A. S. (1988). Credit, Money, and Aggregate Demand. The American Economic Review, 78(2), 435-439.

Bernanke, B. S., \& Gertler, M. (1995). Inside The Black Box: The Credit Channel Of Monetary Policy Transmission (No. 5146). Cambridge.

Bodea, C., \& Hicks, R. (2014). Price Stability and Central Bank Independence: Discipline, Credibility, and Democratic Institutions. International Organization, 69(1), 35-61. https://doi.org/10.1017/S0020818314000277 
Bouoiyour, J., \& Selmi, R. (2013). The Effects of Central Banks' Independence on Inflation Outcomes in Emerging Countries: Does the Choice of Exchange Regime Matter? In Bahmani-Oskooee, M (Eds). Exchange Rates in Developed and Emerging Markets: Practices, Challenges and Economic Implications, 155-180. New York: Nova Science Publisher.

Busse, M., \& Hefeker, C. (2007). Political Risk, Institutions and Foreign Direct Investment. European Journal of Political Economy, 23(2), 397-415. https://doi.org/10.1016/ j.ejpoleco.2006.02.003

Crowe, C., \& Meade, E. E. (2008). Central Bank Independence and Transparency: Evolution and Effectiveness. European Journal of Political Economy, 24(4), 763-777. https://doi. org/10.1016/j.ejpoleco.2008.06.004

Cukierman, A., Webb, S. B., \& Neyapti, B. (1992). The Measurement of Central Bank Independence and its Effect on Policy Outcomes. The World Bank Economic Review, 4(3), 353--398.

Eichengreen, B. (2015). Financial Development in Asia: The Role of Policy and Institutions, with Special Reference to China. Proceeding in Second Annual Asian Monetary Policy Forum, 1-18.

Farvaque, E. (2002). Political Determinants of Central Bank Independence. Economics Letters, 77(1), 131-135. https://doi.org/10.1016/S0165-1765(02)00120-9

Friedman, M. (1968). The Role of Monetary Policy. The Journal of Economic Perspectives, 58(1), 1-17. https://doi.org/http://www.jstor.org/stable/1831652

Garriga, A. C. (2016). Central Bank Independence in the World: ANew Data Set. International Interactions, 42(5), 849-868. https://doi.org/10.1080/03050629.2016. 1188813

Garriga, A. C., \& Rodriguez, C. M. (2019). More Effective than We Thought? Central Bank Independence and Inflation in Developing Countries. Economic Modelling, 85, 87105. https://doi.org/10.1016/j.econmod.2019.05.009

Haan, J. De, \& Eijffinger, S. (2016). The Politics of Central Bank Independence. DNB Working Paper No. 539. Netherlands: De Nederlandsche Bank NV.

Hartwell, C. A. (2019). On The Impossibility of Central Bank Independence: Four Decades of Time (and Intellectual) Inconsistency. Cambridge Journal of Economics, 43(1), 6184. https://doi.org/10.1093/cje/bex083

Hayo, B., \& Hefeker, C. (2001). Do We Really Need Central Bank Independence? A Critical Re-Examination. In Ssrn (No. 01). https://doi.org/10.2139/ssrn.264454

Hayo, B., \& Voigt, S. (2007). Explaining De Facto Judicial Independence. International Review of Law and Economics, 27(3), 269-290. https://doi.org/10.1016/j.irle.2007.07.004

Hielscher, K., \& Markwardt, G. (2012). The Role of Political Institutions for The Effectiveness of Central Bank Independence. European Journal of Political Economy, 28(3), 286-301. https://doi.org/10.1016/j.ejpoleco.2011.08.004

Hove, S., Tchana, F, T., \& Mama, A. T. (2017). Do Monetary, Fiscal and Financial Institutions Really Matter for Inflation Targeting in Emerging Market Economies? Research in 
International Business and Finance, 39(Part A), 128-149. https://doi.org/ 10.1016/j. ribaf.2016.07.025

Ilzetzki, E., Reinhart, C. M., \& Rogoff, K. S. (2017). Exchange Arrangements Entering the 21st Century: Which Anchor Will Hold? NBER Working Paper Series, (23134). https:// doi.org/10.3386/w23134

International Monetary Fund. (2018). Regional Economic Outlook, April 2018, Asia Pacific. In Regional Economic Outlook, April 2018, Asia Pacific. https://doi. org/10.5089/9781484339886.086

Issing, O. (2018). Hawks and Doves: Deeds and Words Economics and Politics of Monetary Policymaking. In Eijffinger, S., \& Masciandaro, D. (Eds.), The uncertain future of central bank independence (pp. 25-32). Retrieved from A VoxEU.org eBook

Khan, M., \& Hanif, W. (2018). Institutional Quality and The Relationship Between Inflation and Economic Growth. Empirical Economics, (August), 1-23. https://doi.org/10.1007/ s00181-018-1479-7

Klomp, J., \& de Haan, J. (2010). Central Bank Independence and Inflation Revisited. Public Choice, 144(3), 445-457. https://doi.org/10.1007/s11127-010-9672-z

Kydland, F. E., \& Prescott, E. C. (1977). Rules Rather than Discretion: The Inconsistency of Optimal Plans. Journal of Political Economy, 85(3), 473-491.

Nagac, A., \& Rizvanoghlu, I. (2018). Central Bank Independence and Economic Performance In Caucasus and Central Asian Countries. Journal of Eastern European and Central Asian Research, 5(2), 10-23. https://doi.org/10.20955/r.75.21-36.

Neyapti, B. (2003). Budget Deficits and Inflation: The Roles of Central Bank Independence and Financial Market Development. Contemporary Economic Policy, 21(4), 458-475. https://doi.org/10.1093/cep/byg025

Oritani, Y. (2010). Public Governance of Central Banks: An Approach from New Institutional Economics. Ssrn, (299). https://doi.org/10.2139/ssrn.1599418

Posen, A. S. (1995). Declaration Are Not Enough: Financial Sector Source of Central Bank Independence. 10, 253-274.

Rochon, L.-P., \& Olawoye, S. (2013). Monetary Policy and Central Banking: New Directions in Post-Keynesian Theory. United Kingdom: Edward Elgar Publishing.

Rogoff, K. (1985). The Optimal Degree of Commitment to an Intermediate Monetary Target. The Quarterly Journal of Economics, 100(4), 1169-1189.

Salahodjaev, R., \& Chepel, S. (2014). Institutional Quality and Inflation. Modern Economy, 5(3), 219-223. https://doi.org/10.4236/me.2014.53023

Stiglitz, J. E. (1998). Central Banking in a Democratic Society. De Economist, 146(2), 199_ 226.

Warjiyo, P., \& Juhro, S. M. (2017). Kebijakan Bank Sentral: Teori dan Praktik (Central Bank Policy: Theory and Practice). Depok: Rajawali Pers. 